\title{
Numerical analysis of residential energy consumption using IoT
}

\section{Análisis numérico del consumo energético residencial usando IoT}

\author{
MARTÍNEZ-ORTIZ, Ana Mercedes †, JUÁREZ-TOLEDO, Carlos*, MARTÍNEZ-CARRILLO, Irma \\ and FLORES-VÁZQUEZ, Ana Lilia
}

Universidad Autónoma del Estado de México

ID $1^{\text {st }}$ Author: Ana Mercedes, Martínez-Ortiz / ORC ID: 0000-0002-1269-8843, CVU CONACYT ID: 1083663

ID $1^{\text {st }}$ Co-author: Carlos, Juárez-Toledo / ORC ID: 0000-0002-7440-3246, Researcher ID Thomson: C-1368-2016, CVU CONACYT ID: 39912

ID $2^{\text {nd }}$ Co-author: Irma, Martínez-Carrillo / ORC ID: 0000-0002-7952-4418, Researcher ID Thomson: B-9264-2016, CVU CONACYT ID: 39914

ID $3^{\text {rd }}$ Co-author: Ana Lilia Flores-Vázquez / ORC ID: 0000-0003-0524-9764, Researcher ID Thomson: C-1325-2016, CVU CONACYT ID: 92382

DOI: $10.35429 / J R E .2021 .14 .5 .14 .21$

Received March 30, 2021; Accepted June 30, 2021

\begin{abstract}
Modern technology has changed our lives in many aspects revolutionizing how we work, live, and communicate. This fourth industrial revolution allows the organizations to be easily monitored and efficient management. The efficiency and supply of electrical energy is important issue for human development. In this work the analysis of the electrical energy of a residential house is approached. The methodology used for the analysis of the efficiency electrical energy is based initially on the determination of the numerical areas to obtain the respective energy consumption. The information obtained is stored in real time in ThingSpeak. NodeMCU comes with the ESP8266, this chip used in the development of the electronic device of this work is open-source Lua based firmware with development board specially targeted for IoT applications. In this paper the numerical integral is used to obtain the energy consumption. The main contribution of this work is obtaining a reliable tool to measure and store data in the cloud in real time.
\end{abstract}

Internet of Things, Numerical Analysis and Energy Consumption

\begin{abstract}
Resumen
La tecnología ha cambiado nuestras vidas en muchos aspectos, revolucionando la forma en que trabajamos, vivimos y nos comunicamos. Esta cuarta revolución industrial permite que las organizaciones sean fácilmente monitoreadas y con una gestión eficiente. La eficiencia y el suministro de energía eléctrica es un tema importante para el desarrollo humano. En este trabajo se aborda el análisis de la energía eléctrica de una vivienda residencial. La metodología utilizada para el análisis de la eficiencia energética eléctrica se basa inicialmente en la determinación de las áreas numéricas para obtener el consumo energético. La información obtenida se almacena en tiempo real en ThingSpeak. NodeMCU viene con el ESP8266, este chip usado en el desarrollo del dispositivo electrónico de este trabajo es un firmware con placa de desarrollo de código abierto basado en Lua especialmente dirigido a aplicaciones IoT. En este trabajo se utiliza la integral numérica para obtener el consumo de energía. El principal aporte de este trabajo es obtener una herramienta confiable para medir y almacenar datos en la nube en tiempo real.
\end{abstract}

Internet de las Cosas, Análisis numérico y Consumo energético

Citación: MARTÍNEZ-ORTIZ, Ana Mercedes, JUÁREZ-TOLEDO, Carlos, MARTÍNEZ-CARRILLO, Irma and FLORESVÁZQUEZ, Ana Lilia. Numerical analysis of residential energy consumption using IoT. Journal Renewable Energy. 2021. 5-14: 14-21

*Correspondence to Author (e-mail: cjuarezt@uaemex.mx)

$\dagger$ Researcher contributing as first author. 


\section{Introduction}

In Mexico, as in other countries, reducing electricity consumption in order to have an impact on the reduction of pollutants caused by the inadequate consumption of fuels necessary for anthropic activities is a central element in the demand and generation of policies aimed at promoting the rational and adequate use of energy within households; it is known that the environmental impact generated by residential energy efficiency is low compared to other sectors, but it is still a sector of study for many researchers because as family members increase the use of electricity tends to increase gradually which may be related to the simultaneity of consumption in Mexican households (Franco \& Velázquez, 2016). Explaining the increase of high consumption domestic electricity consumers, according to SENER data, with an increase of $2.42 \%$ in 2017.

Solutions based on semantic web technologies that exploit the Internet of Things (IoT) technology can support electric energy savings, motivating the change of consumption behavior of building occupants. The system for IoT-based smart energy management facilitate users with specific final consumption as well as personalized recommendations for energy saving and load shifting actions, together with an estimation of their impact on energy use and user comfort (Marinakis \& Doukas, 2018).

As an example, the proposal to promote electric energy saving in Indonesia, in 2018, a real-time feedback system is implemented under an experimental government building room with the aim of granting information to the user and thereby changing their behavior in electric energy use (Susanti \& others, 2018). Although the system is only experimental, it provides the user with relevant information to change their electrical energy consumption habits.

Among other research, Torres in his 2020 publication, Real-time monitoring of residential electrical energy consumption that allows its proper management, proposes an electrical system for real-time monitoring of electrical consumption in residences through telemetric measurement with four IoT $_{\text {based }}$ SCT-013 sensors, allowing the user to observe current and voltage of 4 high consumption appliances in their home, and the total consumption for 30 days in Watts.
The system does not measure other lowconsumption electronic devices in the home, which generate significant energy consumption with prolonged use.

Another proposal is the one presented by Tipán when designing a smart meter using the Raspberry Pi card, considering it as a good proposal for measurement and as a tool to access in real time from anywhere in the world to electricity consumption data and controlling some household appliances reducing consumption (Tipán \& Rumipamba, 2018).

One of the most complete systems for the measurement of electrical energy consumption and a communication with internet, which satisfies necessary requirements such as low cost, easy installation, extreme environmental conditions, accurate measurements of current, voltage, power and visualize costs of electrical energy consumptions (Romero \& Others, 2018). However, its main objective is to reconnect and suspend the electric power service remotely, but it allows the user to have a visualization of residential consumption costs and from there improve their electric power saving culture. Another notable drawback is the installation of the system, which requires knowledge of electricity to perform this activity.

The implementation of a portable electric energy meter with on/off control of devices provides awareness to customers for energy conservation. Thakare assumes that current metering and fixed voltage of $230 \mathrm{~V}$ allow a good approximation of consumption calculation, in his conclusions he suggests performing voltage metering to improve this accuracy condition. The measurement of digital meters is done in microseconds, so it is essential, not only the voltage measurement, but the sample time of the measurements.

He total amount of energy from residential use, personnel transportation, school buildings, everything considered as daily life expenses has a significant value of $40 \%$ of the total global energy use (Amaxilatis, Akrivopoulos, Mylonas, \& Chatzigiannakis, 2017). Some proposals to decrease energy consumption in school buildings is the constructions or modernization of these, considering high costs that might not be justified by the reduction of energy consumptions. 
By focusing a holistic solution towards designing an efficient system along with a sustainable vision, using IoT infrastructure combined with a diverse set of feedback and interface mechanisms, to engage end users in long-term behavioral changes (Amaxilatis, Akrivopoulos, Mylonas, \& Chatzigiannakis, 2017). These behavioral changes of energy uses applied at the residential level with high consumption could generate energy efficiency, such as in school buildings, with benefit to the end user without having to invest in high-cost technologies such as photovoltaic systems or make large-scale structural modifications to residential homes.

\begin{tabular}{|c|c|}
\hline Prototype & ristics \\
\hline $\begin{array}{l}\text { An Advanced IoT-based System } \\
\text { for Intelligent Energy } \\
\text { Management in Buildings. }\end{array}$ & $\begin{array}{l}\text { Suggestions for } \\
\text { saving electricity. }\end{array}$ \\
\hline $\begin{array}{l}\text { Configuration System for Real- } \\
\text { Time Monitoring and } \\
\text { Controlling Electricity } \\
\text { Consumption Behavior. }\end{array}$ & $\begin{array}{l}\text { Reports data to } \\
\text { change energy } \\
\text { consumption. }\end{array}$ \\
\hline $\begin{array}{l}\text { Real-time monitoring of } \\
\text { residential electricity } \\
\text { consumption to allow its proper } \\
\text { management. }\end{array}$ & $\begin{array}{l}\text { Monitoring of } \\
\text { devices with SCT- } \\
013 \text { sensor. }\end{array}$ \\
\hline $\begin{array}{l}\text { Smart Electric Energy Meter } \\
\text { using the Raspberry Pi } \\
\text { Electronic Board. }\end{array}$ & $\begin{array}{l}\text { Current } \\
\text { measurement with } \\
\text { Raspberry Pi. }\end{array}$ \\
\hline $\begin{array}{l}\text { Implementation of a prototype } \\
\text { of a residential electric energy } \\
\text { meter considering the reduction } \\
\text { of non-technical losses due to } \\
\text { theft. }\end{array}$ & $\begin{array}{l}\text { Visualize electric } \\
\text { energy consumption } \\
\text { costs. }\end{array}$ \\
\hline $\begin{array}{l}\text { Implementación de un } \\
\text { dispositivo de monitorización y } \\
\text { control energético basado en } \\
\text { IoT. }\end{array}$ & $\begin{array}{l}\text { On/off control of } \\
\text { devices. }\end{array}$ \\
\hline $\begin{array}{l}\text { An IoT-Based Solution for } \\
\text { Monitoring a Fleet of } \\
\text { Educational Buildings Focusing } \\
\text { on Energy Efficiency. }\end{array}$ & IoT utilization. \\
\hline
\end{tabular}

Table 1 Electricity meters Source: Own Elaboration

This article shows the study of the calculation of energy consumption in a residence through the analysis of the behavior of the measurements made by the prototype electric current meter with specific requirements such as low cost and easy installation without reducing the quality of current measurements with low accuracy errors and implementing the internet of things, allowing the application of a numerical integration method based on a first degree polynomial remotely.
The trapezoid rule method is one of the numerical integration methods known as Newton-Cotes closed (Chapra \& Canale, 2015) allowing the average calculation of power consumed in a residence under the time of one hour as established by the Mexican standard NOM-029-ENER-2017. The implementation of an electric current meter and remote access to information thanks to IoT will allow users with high consumption to make changes in electric energy use, generating energy efficiency.

\section{RMS current measurement}

The electric current monitoring system allows obtaining consumption data of a residential house, the measurements were performed with the non-invasive transformer SCT-013-000. The 0 to $100 \mathrm{~A}$ input current measurement transducer with split ferrite core and 0 to $50 \mathrm{~mA}$ rated current output has purpose current measurement, monitoring and protection for AC motors, lighting equipment, air compressor, etc. With an accuracy of $\pm 1 \%$ under operating temperatures of $-50^{\circ} \mathrm{C} \sim 70^{\circ} \mathrm{C}$, considering all the features to reduce the high current values of the load to levels that can be processed by the electronic circuit board. The SCT-013-000 non-invasive current sensor delivers 0 to $50 \mathrm{~mA}$ nominal AC current and data acquisition is performed with the NodeMCU ESP8266 development board on the analog port with voltage measurement in the range of $0-3.3 \mathrm{~V}$ so signal conditioning is needed. With Ohm's Law the required voltage for the ESP8266 NodeMCU board can be obtained as:

$\mathrm{v}(\mathrm{t})=\mathrm{I}(\mathrm{t}) \mathrm{R}_{L}$

Where $\mathrm{v}(\mathrm{t})$ is amplitude of $1.65 \mathrm{~V}$ accepted by the acquisition board, $\mathrm{I}(\mathrm{t})$ is the peak current of the current sensor and $\mathrm{R}_{\mathrm{L}}$ is the load resistance of the coupled system in Figure 1.

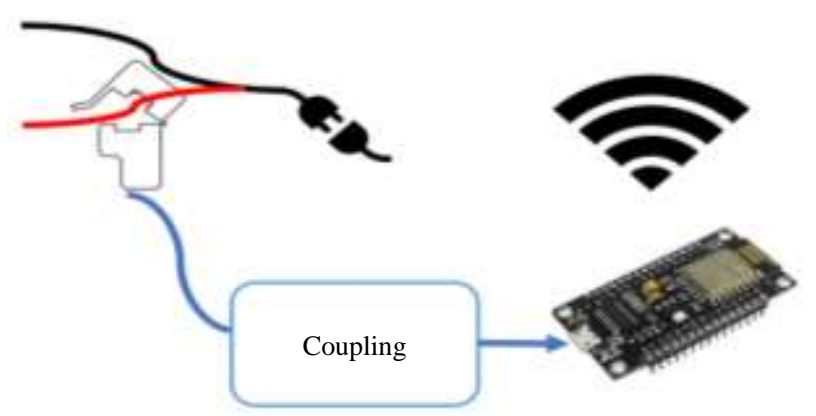

Figure 1 Schematic of electrical current measurement with IoT

Source: Own Elaboration 
The waveform is positively shifted $1.65 \mathrm{~V}$ with a current-stop circuit and filtering of low frequency signals such as noise (Thakare, Shriyan, Thale, Yasarp, \& Unni, Implementation of an Energy Monitoring and Control Device based on IoT, 2016).

The current $I_{R M S}$ is obtained with the relationship of the following equations.

$\mathrm{V}_{\text {filtrar }}=\mathrm{k} *\left(V_{\text {filtrado }}+m-p_{-} m\right)$

Where $V_{\text {filtrado }}$ is a calculated voltage, $\mathrm{m}$ is the current sample value and $p_{-} m$ is the previous sample value, then:

$\mathrm{V}_{\text {rms }}=\sqrt{\frac{\left(V_{\text {filtrar }}\right)^{2}}{\text { Numero de muestras }}}$

Where Numero de muestras is equal to 1024 due to the 10bit ESP8266 NodeMCU board in ADC.

$$
\mathrm{I}_{\text {proporcion }}=\frac{N}{R_{L^{*} *(\text { Numero de muestras })}}
$$

Where $N$ is the number of turns of the secondary winding of the SCT-013-000 transformer. The $I_{R M S}$ value is finally calculated with the following equation (Thakare, Shriyan, Thale, Yasarp, \& Unni, Implementation of an Energy Monitoring and Control Device based on IoT, 2016).

$$
I_{R M S}=\mathrm{I}_{\text {proporcion }} \sqrt{V_{r m s}}
$$

One of the main characteristics of the prototype is the measurement accuracy, for this purpose the calibration is developed resulting in an absolute and relative percentage error of:

$$
\begin{aligned}
& \epsilon=0.0202115 \\
& \epsilon_{r}=2.56687 \%
\end{aligned}
$$

\section{IoT Meter Architecture}

The design of the IoT meter architecture starts with the measurement of electric current with low error by calibration of the equipment designed with low-cost electronics without reducing the quality of the instrument by sending data remotely.
The electric current measurement system is developed under four stages: current sensing (the first stage where the electric current measurement is performed with the SCT013-100 sensor), coupling (in this stage the measured current is transformed into the signal required for data acquisition), data acquisition (with the NodeMCU ESP8266 card, the necessary values are obtained to determine residential consumption) and finally IoT (the acquired data are sent to the ThingSpeak platform where the numerical analysis is performed for the remote observation of energy consumption), as shown in Figure 2.

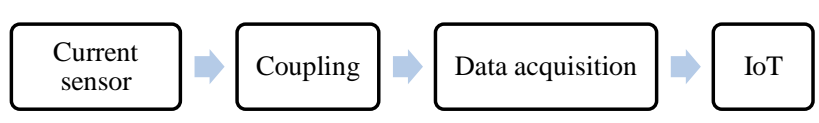

Figure 2 Block diagram of the residential real-time consumption monitoring system

Source: Own Elaboration

The IoT meter must have the basic requirements of existing meters.

$\begin{array}{ll}- & \text { Low cost } \\ - & \text { Easy installation } \\ - & \begin{array}{l}\text { Current measurements with lower } \\ \text { percentage of error }\end{array} \\ -\quad \begin{array}{l}\text { Measurements with sample time in } \\ \text { seconds }\end{array} \\ -\quad \begin{array}{l}\text { Real-time remote display of energy } \\ \text { consumption }\end{array} \\ -\quad \begin{array}{l}\text { Numerical integral application with IoT } \\ \text { Instant messaging when approaching } \\ \text { monthly demand of 250kWh }\end{array}\end{array}$

For the low cost of the meter and the use of IoT, the implementation of non-invasive current sensors is considered in order not to modify the existing installation in the house and the use of a free data visualization is implemented, without the need to pay for the domain or server to store the data. Taking into account these parameters we also comply with the easy installation of the current meter.

The coupling study of the selected transducer signal will allow measurements with low error and sample time in seconds; the use of a free data storage service and user-friendly consumption graphs will meet the requirement of visualization of electrical energy consumption costs. 
The electrical diagram (see figure 3) shows part of the architecture of the electric current meter, the current sensing consists of the connection of the SCT013-100 sensor, and the signal coupling is observed with the connection of the load resistor R_L and the AC signal displacement circuit with filtering. The LM158 operational amplifier is configured as a voltage follower allowing to limit the signal from undesirable peaks. Finally, we have the connection to the analog input of the NodeMCU ESP8266 development board where the data acquisition and IoT stages are developed.

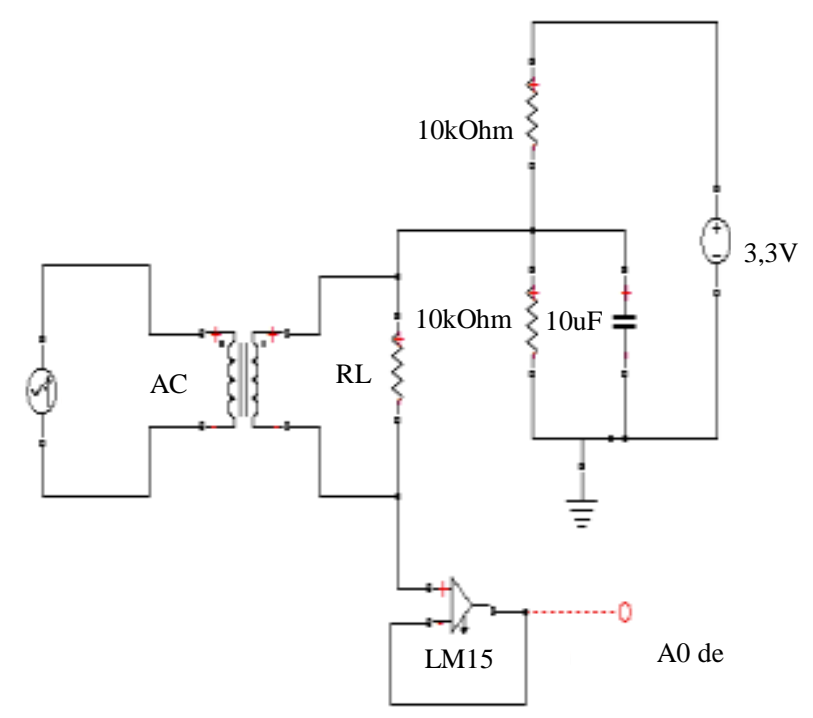

Figure 3 Electrical diagram of IoT meter Source: Own Elaboration

The Internet of Things (IoT) makes it possible to collect data from many activities, including the energy consumption of hundreds of factories and thousands of homes in near real time. This wealth of information has opened up opportunities to evaluate energy efficiency initiatives and predict energy demand.

As part of the electric current meter, the Internet of Things is implemented using the ESP8266 NodeMCU platform with core to the ESP-12E SoM which internally is based on the ESP8266 WiFi SoC.

The ESP8266 SoC (System On a Chip) from Espressif Systems is a chip specially designed for the needs of a connected world, integrating a powerful microcontroller with 32bit architecture and WiFi connectivity. The ESP12E SoM (System on Module) manufactured by Ai-Thinker integrates in one module the ESP8266 SoC, FLASH memory, oscillator crystal and WiFi antenna on PCB.
Figure 4 shows the flowchart used in the programming of the ESP8266 NodeMCU card where the electrical current measurement cycle of the residence can be observed.

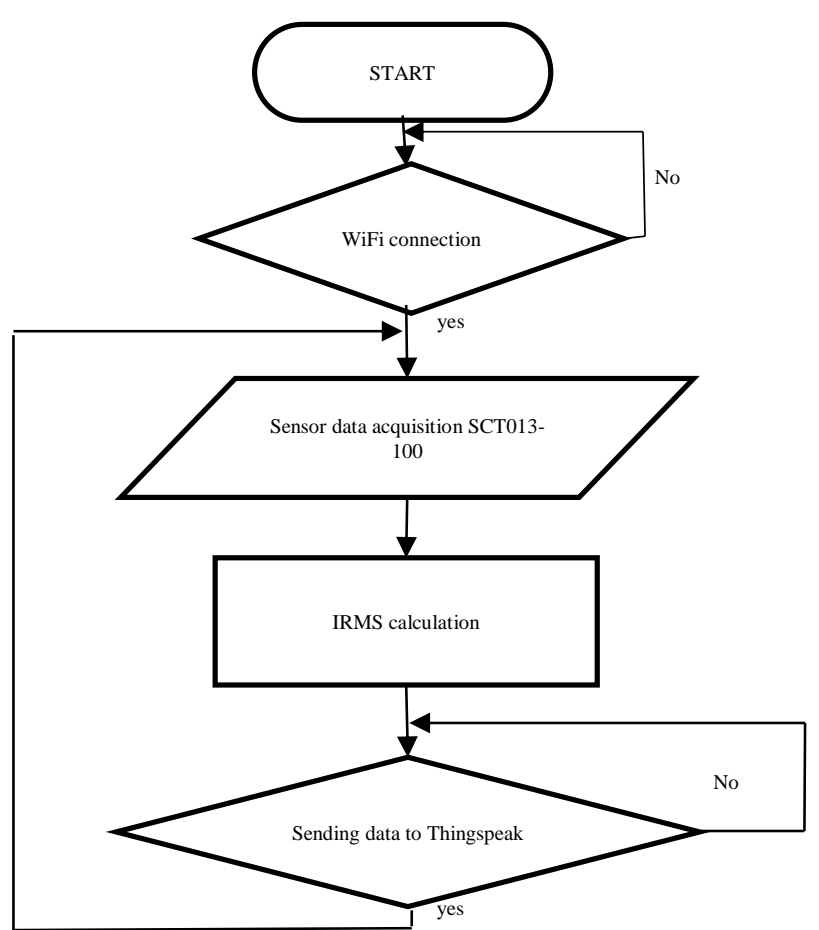

Figure 4 IoT meter flow diagram Source: Own Elaboration

ThingSpeak ${ }^{\mathrm{TM}}$ was used to monitor and store energy usage in order to achieve operational efficiency goals.

ThingSpeak is an online platform for instant data visualizations where you can run MATLAB ${ }^{\circledR}$ codes and perform online analysis and data processing with live data and view automatic visualizations.

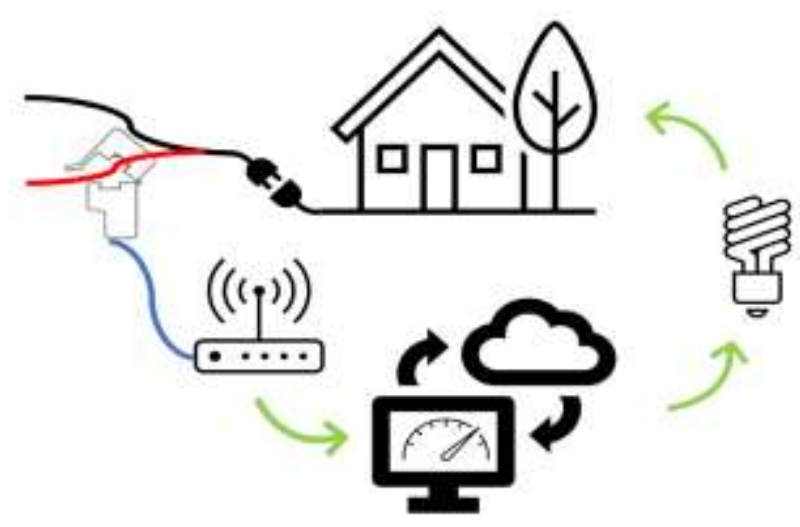

Figure 5 Schematic of the residential real-time consumption monitoring system Source: Own Elaboration 


\section{Results}

The data shown in the ThingSpeak page in public channels are current, power and energy consumption.

Graph 1 shows the energy consumption in units of Amperes RMS, where important information is observed, the consumption behavior is determined that in the house of the prototype application there are loads greater than $2.5 \mathrm{~A}$ and the time of use.

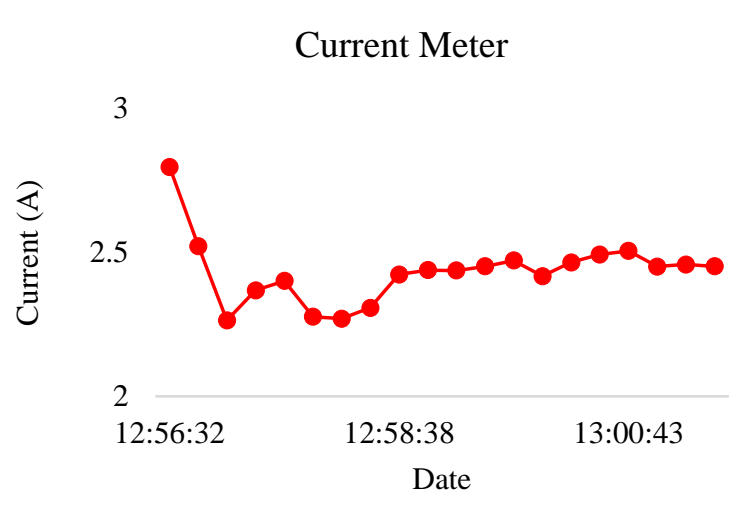

Graph 1 Graph of the current measured in real time Source: Own Elaboration

The power consumed is calculated by means of IoT with working equation 6 .

$\mathrm{P}=\frac{\mathrm{VI}}{1000}(\mathrm{~kW})$

Se considera un voltaje eficaz de $127 \mathrm{~V}$ para obtener el potencial consumido por cada muestra de corriente en unidades de $\mathrm{kW}$ como se muestra en el gráfico 2.

\section{Power}

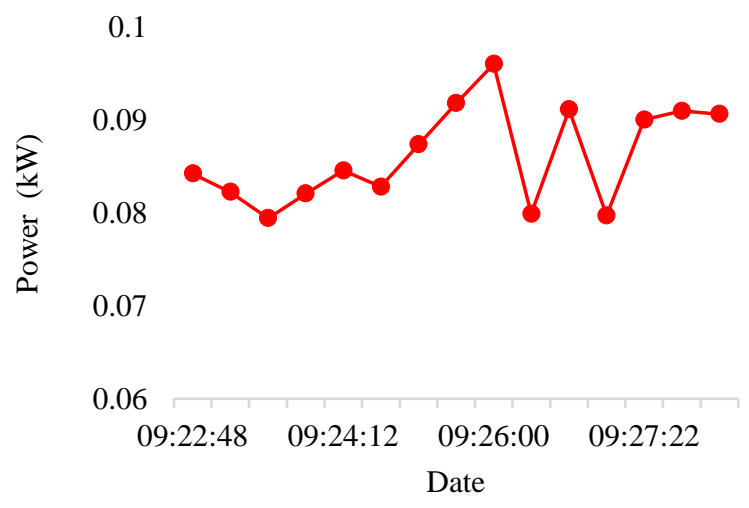

Graph 2 Real-time power calculation graph Source: Own Elaboration
Residential energy consumption is measured in units of kilo Watts hour, based on the need to sum up all energy consumption during the period of hours, multiple tools can be used, including integration or the use of numerical integration methods such as the trapezoid rule.

The trapezium rule is the first of the closed Newton-Cotes integration formulas on the closed interval $[a, b]$ (Chapra \& Canale, 2015).

$I_{T}=\int_{a}^{b} f_{1}(x) d x$

The method integrates the first degree polynomial, line segments in each power calculation:

$f_{1}(x)=f(a)+\frac{f(b)-f(a)}{(b-a)}(x-a)$

The area under the approximation line (equation 8 ) between the closed interval $[a, b]$ allow to obtain the trapezoid rule between two samples of consumed power.

$I_{T}=(b-a) \frac{f(a)+f(b)}{2}$

The trapezoid method approximates the integration with easy-to-calculate trapezoid areas, considering uniform spaces. The IoT meter performs uniform sampling as shown in Figure 3 with daily average of 16 seconds (ThingSpeak platform allows monitoring data every 15 seconds), so the implementation of the integration method is advantageous.

Average: 16 seconds

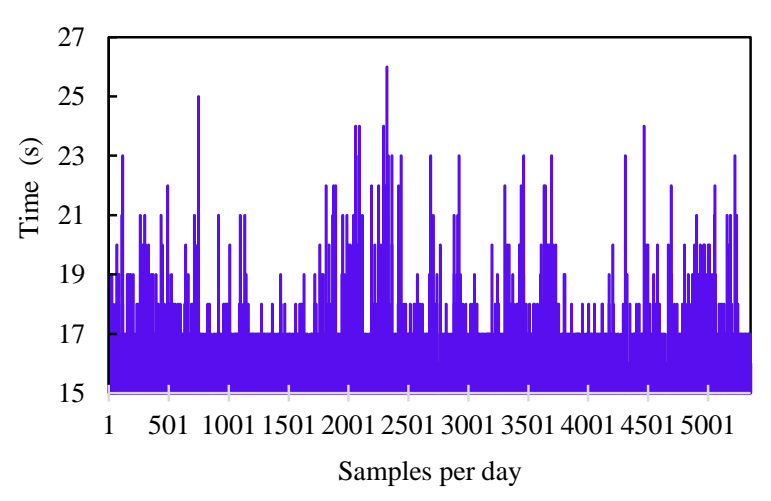

Graph 3 Sampling time with IoT Source: Own Elaboration

The trapezium formula is generalized for non-constant intervals.

MARTÍNEZ-ORTIZ, Ana Mercedes, JUÁREZ-TOLEDO, Carlos, MARTÍNEZ-CARRILLO, Irma and FLORES-VÁZQUEZ, Ana Lilia. Numerical analysis of residential energy consumption using IoT. Journal Renewable Energy. 2021 
$I_{T}=\frac{1}{2} \sum_{i=1}^{n}\left(x_{i+1}-x_{n}\right)\left[f\left(x_{n}\right)+f\left(x_{i+1}\right)\right]$

When using an integral under a straight line segment under a curve, a local truncation error estimate is used as seen in equation 11.

$I_{T}=(b-a) \frac{f(a)+f(b)}{2}-\epsilon_{t}$

Where $\epsilon_{t}$ is the local truncation error and is calculated:

$\epsilon_{t}=\frac{1}{12} f^{\prime \prime}(\xi)(b-a)^{3}$

In the application of this method in the study of energy consumption calculation does not correspond $\epsilon_{t}$ due to the local intervals of $[a, b]$ there is a straight line segment so the error decreases.

The basic requirements of the system to calculate residential energy consumption result that the low cost was achieved with the application of the NodeMCU ESP8266 development board, a board considered rudimentary allowed us to obtain expected results; the use of the non-invasive sensor SCT013-000 allows an easy installation of the prototype without intervening in the existing installation in the dwelling house; the current measurements with a percentage relative error rate of $2.56 \%$ thanks to the application of a signal coupling; the ThingSpeak platform allows the observation of the measurements with sample time in 16 seconds and the real-time remote visualization of energy consumption. The implementation of the numerical method through cloud programming of the trapezoidal integral allows obtaining residential energy consumption, as in Figure 4, in standard measurement units $(\mathrm{kWh})$.

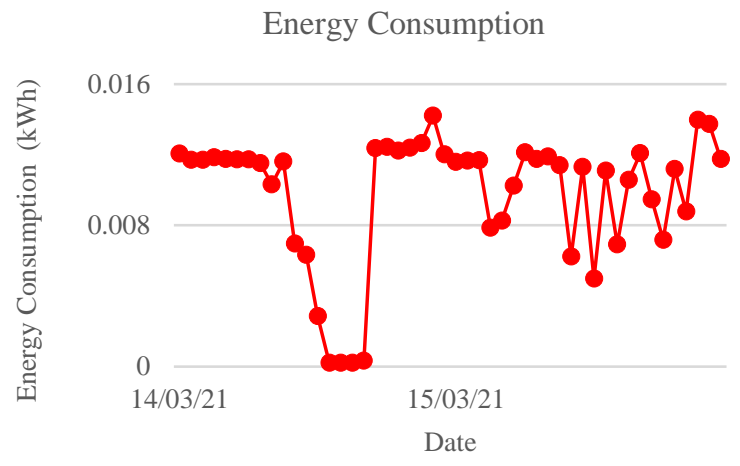

Graph 4 Real-time kWh consumption graph Source: Own Elaboration

The energy consumption measurement prototype allows the visualization of the daily consumption in kilo Watts hours remotely. As shown in graph 5, the visualization is user friendly, recognizing the real daily amounts of electric energy use in the user's home, allowing the identification of favorable energy consumption habits.

Daily Consumption

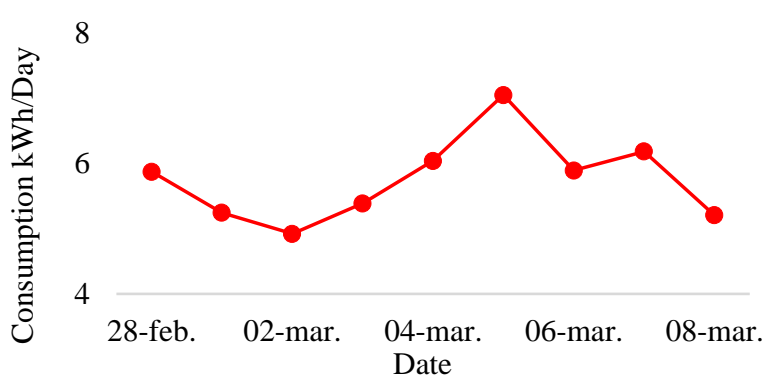

Graph 5 Graph of kWh consumption per day in real time Source: Own Elaboration

\section{Acknowledgements}

To the National Council of Science and Technology (CONACYT) Mexico.

\section{Conclusions}

High consumption appliances are essential in the home (refrigerator, heating, etc.) so they cannot be eliminated, as the decrease in the time of use of these appliances can generate energy efficiency in residences.

\begin{tabular}{|l|r|l|}
\hline \multicolumn{1}{|c}{ Apparatus } & \multicolumn{1}{c|}{$\begin{array}{c}\text { Power } \\
\text { (average } \\
\text { watts) }\end{array}$} & $\begin{array}{c}\text { Time of use } \\
\text { (typical } \\
\text { periods) }\end{array}$ \\
\hline Bomba de agua & 400 & 20 min / day \\
\hline Music stereo & 75 & 4 hrs per day \\
\hline $\begin{array}{l}\text { Fluorescent spotlights } \\
\text { (8 of 15 W w/u) }\end{array}$ & 120 & 5 hrs per day \\
\hline Microwave oven & 400 & $\begin{array}{l}45 \text { min / day } \\
\text { wk times / }\end{array}$ \\
\hline Automatic Washer & 400 & 10 min / day \\
\hline $\begin{array}{l}\text { Medium } \\
\text { blender. }\end{array}$ & 300 & 4 hrs per day \\
\hline Computer equipment & 480 & 5 hrs per day \\
\hline $\begin{array}{l}\text { Incandescent } \\
\text { spotlights (8 of 60W } \\
\text { w/u) }\end{array}$ & 120 & 6 hrs per day \\
\hline $\begin{array}{l}\text { TV color (24 29 } \\
\text { pulgadas) }\end{array}$ & 500 & 9 hrs per day \\
\hline $\begin{array}{l}\text { Refrigerator more } \\
\text { than 10 years old }\end{array}$ & &
\end{tabular}

Table 2 Average consumption of household appliances Source: Own Elaboration 
Table 2 shows the average power consumption of some typical residential appliances along with an average ideal usage to obtain low energy consumption. The visualization of power by hours in a day consumed in homes and having the knowledge of average consumption of some appliances remotely will allow the user to decide new habits of energy use.

The monthly energy consumption limit is $250 \mathrm{kWh}$, this means that if the residence is above this margin is considered a High Consumption user, so the implementation of instant messaging within the remote communication system, IoT, will alert the user to reduce energy consumption by implementing better times of use of appliances.

Typically the use of a computer equipment is 4 hours per day and an average power of 300 watts, by having the information of its previous daily consumption and its instant messaging, the user will determine the time to turn on the device to control its consumption (see Table 2).

\section{Referencias}

Amaxilatis, D., Akrivopoulos, O., Mylonas, G., \& Chatzigiannakis, I. (2017). An IoT-Based Solution for Monitoring a Fleet of Educational Buildings Focusing on Energy Efficiency. Sensors 2017, 17, 2296.

Chapra, S. C., \& Canale, R. P. (2015). Métodos númericos para ingenieros (Séptima ed.). Mc Graw Hill Education.

CRE, C. R. (25 de Mayo de 2020). gob.mx. Recuperado el 23 de Noviembre de 2020, de https://www.gob.mx/cre/articulos/consulta-lasmemorias-de-calculo-de-las-tarifas-

electricas? state $=$ published

Domoticalia. (s.f.). Recuperado el 16 de 11 de 2020 , de https://www.domoticalia.es/es/6_aeotec

FIDE. (18 de Febrero de 2021). Fideicomiso para el Ahorro de Energía Eléctrica - FIDE. Recuperado el 04 de Marzo de 2021, de https://www.fide.org.mx/?page_id=42802\#
Franco, A., \& Velázquez, M. (2016). Una aproximación sociodemográfica al consumo de energía en los hogares mexicanos, 2014. Recuperado el 28 de 09 de 2020, de CONAPO, México:

https://www.gob.mx/cms/uploads/attachment/fi le/232092/07_Franco_Velazquez.pdf

Marinakis, V., \& Doukas, H. (2018). An Advanced IoT-based System for Intelligent Energy Management in Buildings. Sensors 2018, 18, 610 .

NORMA Oficial Mexicana NOM-029-ENER2017. (21 de julio de 2014). Diario Oficial de la Federación.

Romero, E., \& Otros. (2018). Implementación de un prototipo de medidor de energía eléctrica residencial considerando la reducción de pérdidas no técnicas por hurto. Revista Publicando, 5(15), 66-82.

Susanti, L., \& others, a. (2018). Configuration System for Real-Time Monitoring and Controlling Electricity Consumption Behavior. International Conference on Information Technology Systems and Innovation (ICITSI) (pág. 44). Indonesia: Bandung - Padang.

Thakare, S., Shriyan, A., Thale, V., Yasarp, P., \& Unni, K. (2016). Implementation of an Energy Monitoring and Control Device based on IoT. Conference of the IEEE India 2016 (INDICON) . India: INDICON.

Thakare, S., Shriyan, A., Thale, V., Yasarp, P., \& Unni, K. (2016). Implementation of an Energy Monitoring and Control Device based on IoT. IEEE Annual India Conference (INDICON) (págs. 1-6). Bangalore, India: Electronics and Telecommunication Engineering. doi:10.1109 / INDICON.2016.7839066.

Tipán, L., \& Rumipamba, J. (2018). Medidor Inteligente de Energía Eléctrica utilizando la Tarjeta Electrónica Raspberry Pi. Revista Técnica “energía”, 14, 131-139.

Torres Quijije, A. I., Pisco Vanegas, J. C., Pérez Parraga, R. S., \& Vera García, I. G. (2020). Monitoreo en tiempo real del consumo. Universidad y Sociedad, 12(2), 218-222. 